удк 351: 61(477)

А.Г. Гавриченко,

к. мед. н., завідувач кафедри анестезіології, інтенсивної терапї та медичини болю,

Одесъкий медичний інститут Міжнародного гуманітарного університету

ORCID ID: 0000-0003-1595-4467

DOI: $10.32702 / 2306-6814.2021 .22 .120$

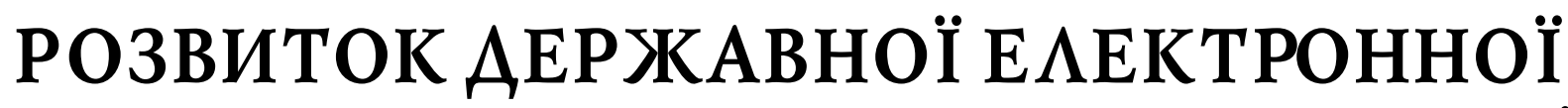 СИСТЕМИ ОХОРОНИ ЗАОРОВ'Я В УКРАЇНI
}

\author{
D. Havrychenko, \\ $\mathrm{PhD}$ in Medical Sciences, Head of the Department of Anesthesiology, Intensive Care \\ and Pain Medicine, Odesa Medical Institute of the International Humanitarian University
}

\section{DEVELOPMENT OF THE GOVERNMENT ELECTRONIC HEALTH SYSTEM IN UKRAINE}

\begin{abstract}
Устатті розглянуто етапи інформатизації системи охорони здоров 'я в умовах реформування системи. Визначено основні напрями розвитку та впровадження електронної системи охорони здоров'я. Доведено, що розвиток е-медицини сприяє покращенню та швидкості медичного обслуговування населення та дозволить трансформувати сферу охорони здоров'я в бік європейських та міжнародних стандартів. Проаналізовано впровадження електронних послуг та медичних інформаційних систем на першому етапі реформування системи охорони здоров'я України. Визначено основні механізми провадження електронної медичної картки, електронного рецепту та виявлено переваги його використання для медичних закладів, для аптечних закладів та загалом для сфери охорони здоров'я. Впроваджені механізми надали змогу виявити недоліки електронної системи охорони здоров'я та запропонувати подальші кроки її розвитку: ведення медичної документації в електронному вигляді; впровадження інформаційних автоматизованих галузевих систем; удосконалення розвитку системмоніторингу стану здоров'я населення; подальша діджиталізація сфери охорони здоров'я України.
\end{abstract}

The article considers the stages of informatization of the health care system in the conditions of system reform. The main directions of development and implementation of the electronic health care system are identified. It has been proven that the development of e-medicine contributes to the improvement and speed of medical care and will transform the healthcare sector in the direction of European and international standards. The introduction of electronic services and medical information systems at the first stage of reforming the health care system of Ukraine is analyzed. It is proved that the new IT services will strengthen the capacity in the field of monitoring, implementation, planning of programs in the field of health care. The main mechanisms of making an electronic medical card, electronic prescription are determined. Medical information systems (helsi, EMCIVED, Medics, "Polyclinic without queuing") are provided, which provide centralized storage of data of health care institutions and allow the National Health Service of Ukraine and the Ministry of Health of Ukraine to process impersonal data and analyze them for quality management of medical services and effective management of the health care system. The advantages of using an electronic prescription for medical institutions, for pharmacies and for health care in general are systematized. It is determined that for further informatization of medicine it is necessary to use global information technologies, adhere to the common world standards of storage, processing, exchange, collection of electronic version of medical information. It is substantiated that the development of electronic identification infrastructure will promote the development of electronic forms of interaction between the state and citizens, provide safe and convenient access to interactive tools, electronic services. The 
implemented mechanisms made it possible to identify the shortcomings of the electronic health care system and suggest further steps for its development: keeping medical records in electronic form; introduction of automated sectoral information systems, improvement of the development of public health monitoring systems, further digitalization of the health care sector of Ukraine.

КлючоВі слова: електронна система, держаВне регулюВання, охорона здоров'я, електронний рецепт, електронна медична картка.

Key words: electronic system, government regulation, health care, electronic prescription, electronic medical card.

\section{ПОСТАНОВКА ПРОБАЕМИ}

Закінчення першого етапу реформування у сорері охорони здоров'я надали змогу виявити актуальні питання розвитку окремих напрямів. Розвиток та впровадження державою електронної системи охорони здоров' я мають за завдання забезпечити можливості використання пацієнтами електронних сервісів для реалізації їх прав, автоматизацію ведення обліку медичних послуг і управління медичною інформацією, запровадити електронний документообіг у срері медичного обслуговування населення. Всі ці завдання набувають актуальності у процесі реалізації Програми діяльності Уряду України [1] щодо забезпечення заходів спрямованих на подолання пандемії COVID-19, запровадження ведення медичної документації в електронному вигляді; підвищення якості практичної підготовки лікарів-інтернів та як результат - підвищення якості надання медичної допомоги населенню; забезпечення рівного доступу до якісної медичної допомоги громадян.

\section{AHA $\Lambda$ IЗ OCT AHHIX АОС $\Lambda$ IАЖЕНЬ І ПУБАІКАЦІЙ}

Питанням формування та розвитку державної електронної системи охорони здоров'я в Україні приділялось достатньо уваги такими вченими: Баценко Д. [2], Брагінський П. [2], Бучма М. [2], Орлова Н. [3], Радиш Я. [4], Устінов О. [5]. та ін. Попри те, що дискусія щодо розвитку електронної системи охорони здоров'я ведеться протягом останніх п'яти років, відсутня єдина думка як щодо визначення напрямів розвитку електронної системи охорони здоров'я в умовах цифрових трансформацій.

\section{МЕТА РОБОТИ}

Метою роботи є визначити напрями розвитку електронної системи охорони здоров'я в умовах цифрових трансформацій для підвищення ефективності взаємодії держави та громадян України.

\section{ВИКААА ОСНОВНОГО МАТЕРІААУ}

До складу електронної системи охорони здоров'я відносять центральну базу даних та електронні медичні інформаційні системи, обмін документами, даними, інфрормацію між якими забезпечено через відкритий програмний інтерсрейс.

Автоматизація управління медичною інформацією та ведення обліку медичних послуг, для реалізації прав пацієнтів за програмою державних гарантій медичного обслуговування населення забезпечення можливості використання пацієнтами електронних сервісів, запровадження у сорері медичного обслуговування населення електронного документообігу за програмою медичних гарантій $є$ головними завданнями електронної системи охорони здоров'я.

Постановою Кабінету Міністрів України від 25 квітня 2018 р. №411 "Деякі питання електронної системи охорони здоров'я" регламентуються Порядок опублікування відомостей з електронної системи охорони здоров'я Національною службою здоров'я України (НСЗУ) та Порядок функціонування електронної системи охорони здоров'я [6]. В Порядку функціонування електронної системи охорони здоров'я визначені фрункціональні можливості електронної системи охорони здоров'я. Впровадження таких можливостей проводиться відповідно до етапів реалізації фрінансових державних га-

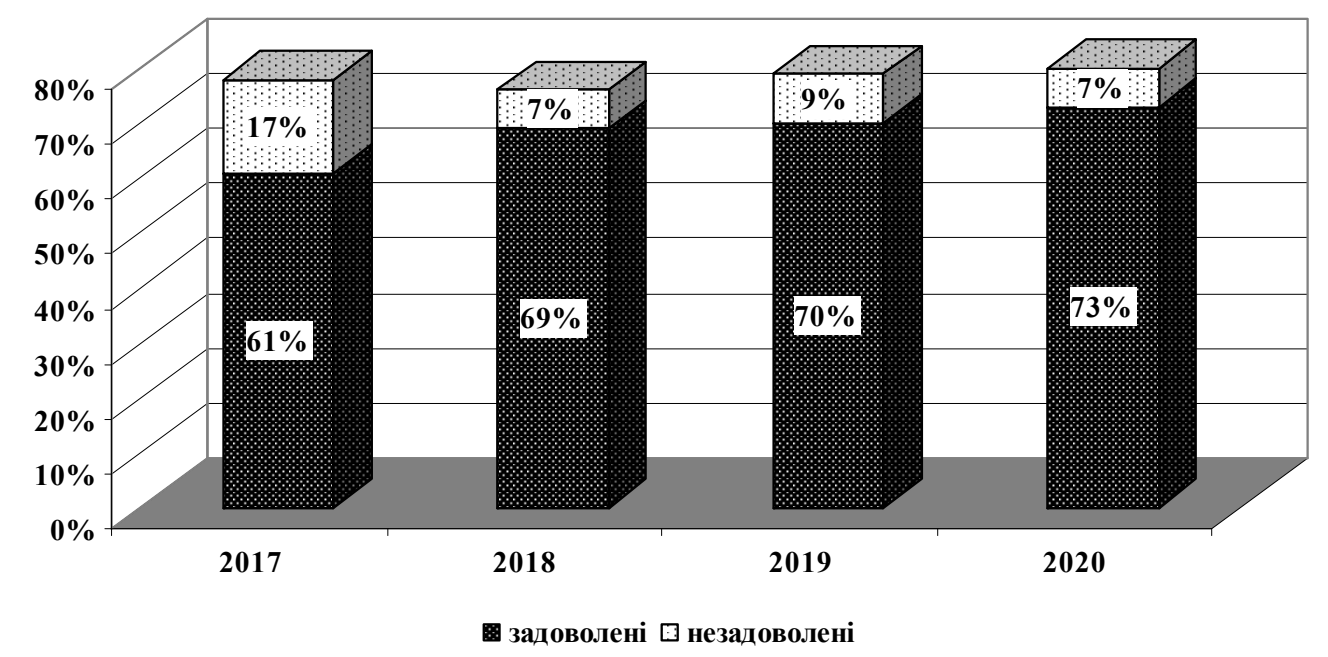

Рис. 1. Задоволеність громадян сімейним лікарем в 2017-2020 рр. Джерело: [7; 9]. 
рантій медичного обслуговування населення та впроваджуються поступово відповідно до Закону України "Про державні фрінансові гарантії медичного обслуговування населення". Тому важливим $€$ підключення до Електронної системи охорони здоров'я всіх медичних закладів, які реалізовують програму фрінансових державних гарантій медичного обслуговування населення. Отримувати фрінансування від НСЗУ за новою моделлю фінансування медичних закладів зможуть тільки ті заклади, які правильно ввели декларації з пацієнтами, правильно ввели інформацію про місця надання первинної медичної допомоги, надавачів медичних послуг та підключились до Електронної системи охорони здоров'я [7].

Впровадження медичної електронної системи має передусім полегшити життя громадянам, оскільки вона передбачає запис на прийом до лікаря без багатогодинного очікування черги - в режимі онлайн. Різні соціологічні опитування показують такі тренди в охороні здоров'я: стабільно високу довіру до свого лікаря, поступову відмову від практики хабарів, позитивну оцінку програм забезпечення ліками. За результатами дослідження Київського міжнародного інституту соціології робота Міністерства охорони здоров'я України $є$ важливою для $81 \%$ населення країни.

Міністерство охорони здоров'я регулює впровадження eHealth на нормативно-правовому рівні. НСЗУ укладає договори з постачальниками медичних послуг; аналізує та використовує дані з метою прогнозування потреб населення у медичних послугах, розробки програми медичних гарантій, встановлення тарифів, здійснення моніторингу договорів; здійснює оплати за медичні послуги на умовах договору [8].

Якщо у жовтні 2016 року лише 55\% респондентів знали своїх сімейних лікарів, то після прийняття закону про трансформацію системи охорони здоров'я (осінь 2017 року) цей показник зріс до $66 \%$ протягом року та досяг $81 \%$ у 2019 році (рис. 1). Ці показники є важливими, адже саме на рівні сімейних лікарів у світі вирішуються понад $80 \%$ питань щодо здоров'я.

Вільно обирати своїх лікарів - сімейних, терапевтів і педіатрів - громадяни України почали 3 квітня 2018 року. Соціологічні опитування показують стабільно високий рівень довіри до свого лікаря.

За програмою "Доступні ліки" пацієнти із хронічними захворюваннями отримують ліки безоплатно чи з незначною доплатою. Нині це 240 препаратів від 50 різних виробників (серед них як українські компанії, так і 12 іноземних компаній). За офріційними даними Міністерства охорони здоров'я України і з згідно з соціологічними опитуваннями, приблизно 20\% українців регулярно користуються програмою: отримують ліки в аптеках за електронним рецептом, а НСЗУ компенсує витрати для аптек [7].

Опитування показали, що понад 90\% респондентів схвалює нову програму, адже вона гарантує ліки безоплатно чи за зниженою ціною. З жовтня 2017 року май-

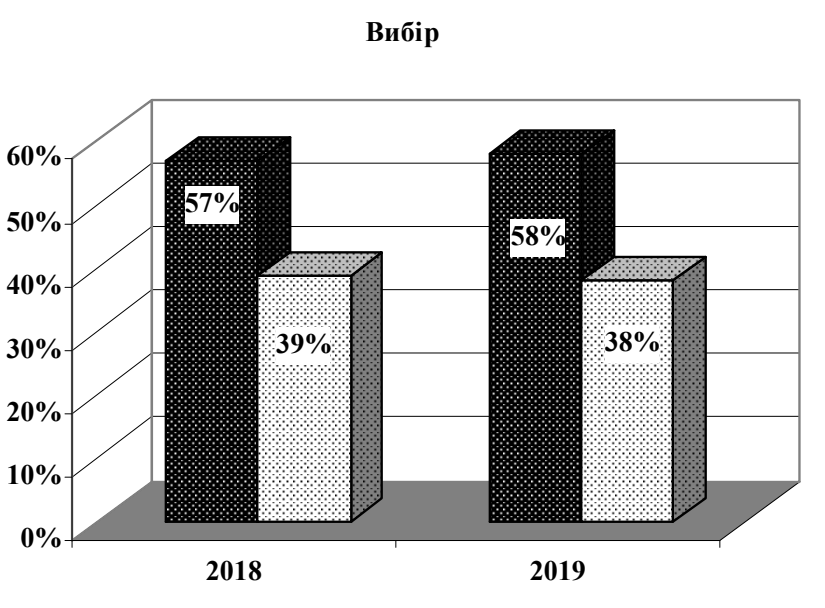

웅 задоволені 0 незадоволені

Якість

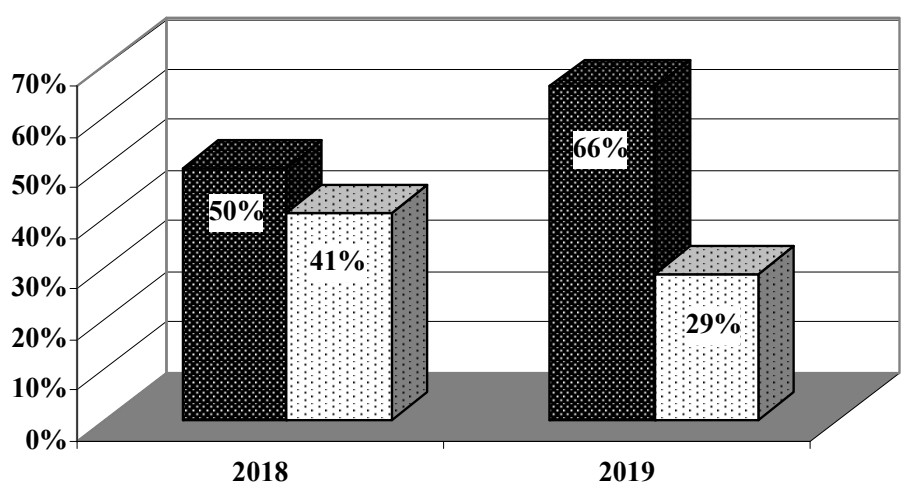

В задоволені $\square$ незадоволені

Вважають успішною

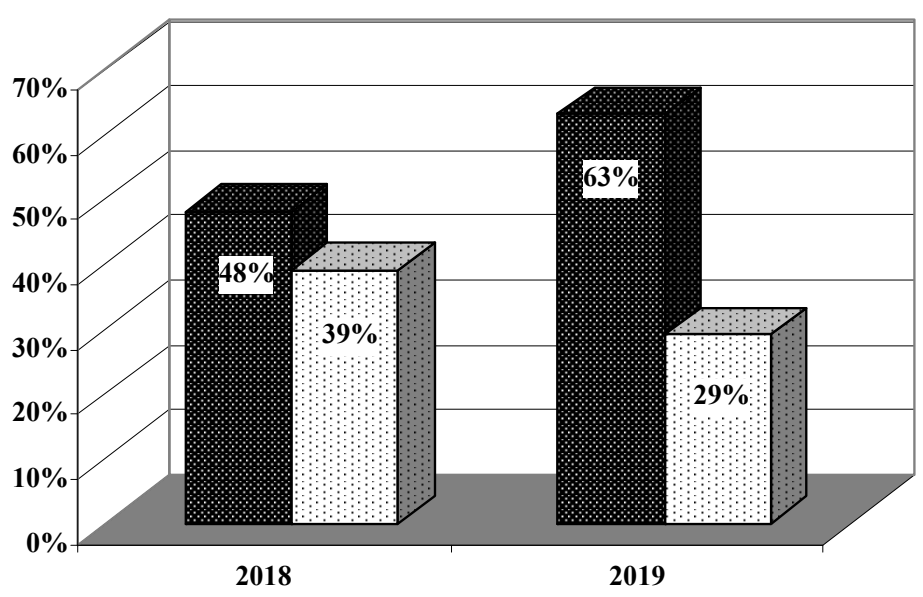

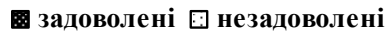

Рис. 2. Задоволеність громадян України програмою "Доступні ліки" в 2018-2019 рр., \%

Джерело: [7; 9].

же не змінилась оцінка респондентів кількості аптек (у програмі бере участь кожна третя аптека країни) та задоволення різноманітністю медичних препаратів. Проте за останні 5 місяців рівень задоволення якістю ліків значно підвищився від $50 \%$ до $66 \%$ (рис. 2).

Для подальшої інфрорматизації медицини необхідним $€$ глобальне застосування інфоомаційних техно- 
логій, дотримання єдиних світових стандартів збереження, обробки, обміну, збору електронного варіанту медичної інформації. Триває робота щодо інтеграції системи з іншими державними реєстрами для здійснення заходів з верифікації. Це дасть можливість отримати 3 таких реєстрів дані.

На початку жовтня 2018 року НСЗУ введено в дію контакт-центр за коротким номером 16-77. Відповіді на найбільш поширені питання доступні в автоматичному режимі цілодобово. Подзвонивши в робочий час, існує можливість поставити питання оператору. Питання, вирішення яких потребує додаткового часу, скеровуються для вирішення та реєструються у відповідні підрозділи НСЗУ. Після розв'язання питання оператори надають повну інформацію про вирішення запиту. Дзвінки з мобільних операторів та зі стаціонарних телефонів $\epsilon$ безкоштовними.

Запуск в медичній сорері електронних послуг з ліцензування (онлайн отримання ліцензії на імпорт, продаж, виробництво ліків) та ведення електронних карток заплановано найближчим часом, що забезпечить ще більшу прозорість [10].

Нові ІТ-послуги на рівні Міністерства охорони здоров'я дозволять зміцнити потенціал у сорері моніторингу, реалізації, планування програм у галузі охорони здоров'я. Нові послуги електронної системи охорони здоров'я (наприклад, використання електронного рецепту) можуть поліпшити розподіл ресурсів, підвищити для громадян якість та доступність медичних послуг, для постачальників послуг - підтримати ефективніший процес обслуговування. Поєднати різні інформаційні системи через різні протоколи дозволить створення безпечного обміну.

Першим етапом було формування єдиного реєстру медичних закладів. Інформація, яка була вноситися в базу: про місце реєстрації, місце знаходження, керівника, ліцензування, номер мобільного і адресу електронної пошти, куди передається інформація про пароль доступу до аккаунту. Після цього відбулося створення профрілю та підтвердження за допомогою електронного цифрового підпису медичної установи як юридичної особи. Після реєстрації медичного закладу вноситилися дані про лікарів: ім'я, контакти, освіта, кваліфрікація, спеціальність. В першучергу реєструвалися саме сімейні лікарі. Наступним кроком було створення декларації (заяви) між лікарем і пацієнтом.

Кожна лікарня має змогу вирішити, в якій медичній інформаційній системі (MIC) вона хоче працювати. МIC розрізняються між собою формою своєї організації і інтерфейсом. Але на кінцевий результат - внесення інфрормації в єдину базу даних - вибір МIC не впливає. Лікарні можуть вибрати між чотирма MIC (helsi, EMCIVED, Medics, "Поліклініка без черги").

Через MIC, які встановлені в закладах охорони здоров'я, збираються дані до електронної медичної картки та відправляються до Центральної бази даних. Завдяки централізованому зберіганню даних: для управління якістю медичних послуг НСЗУ може аналізувати дані; для ефективного управління системою охорони здоров'я НСЗУ та Міністерство охорони здоров'я України можуть обробляти знеособлені дані; дані гарантовано доступні для лікаря, який його обслуговує, та пацієнта. Незалежно від того, чи $є$ зв'язок з Інтернетом у закладі, з якого вносилась інформація, чи працюють там сервери доступ до централізованих даних наявний. Ключові дані зберігаються в централізованій системі, тому медичні заклади можуть переходити з однієї МІC на іншу без втрат інформації [11].

Система "Електронне здоров'я", в якій знаходяться дані електронної медичної картки, знаходиться на серверах дата-центру в Україні, акредитовані у Державній службі спеціального зв'язку та захисту інформації, 3 комплексною системою захисту інформації.

Отже, важливим питанням в процесі адміністрування електронних послуг в закладах охорони здоров'я $€$ формування єдиного електронного медичного простору, що має бути вирішеним за допомогою інтенсивного використання інформаційних технологій. Поряд 3 цим виникає й проблема зростання обсягів інформаційних потоків. Тому необхідним було вдосконалення державних механізмів опанування й використання медичної інформації, її раціонального збирання та аналізу шляхом впровадження електронної медичної картки.

Електронна медична картка (ЕМК) $є$ головним компонентом інформаційної системи охорони здоров'я, яка містить результати оглядів лікаря, реєстраційні дані, різноманітні графрічні дані, лабораторні обстеження (ультразвукова діагностика, рентген, тощо), антропометричні виміри. При введенні даних в ЕМК не застосовується унікальна технологія деревовидних шаблонів, яка дозволяє використовуючи стандартний набір професійних виразів та термінів формувати звіти оглядів.

При цьому медсестрі чи лікарю достатньо вибрати у спеціально розроблених шаблонах огляду необхідні вирази та слова з переліку запропонованих. У шаблоні для зручності роботи налаштовані інтерактивні підказки, виділення кольором, відповіді по замовчуванню. Контроль за повнотою та правильністю введення інфрормації під час фрормування медичного документу здійснюється автоматично.

Лікарі кодують у електронній картці скарги пацієнта та діагнози за міжнародною системою ICPC-2. Поступово з розширенням функції електронних карток лікарі зможуть формувати повноцінну ЕМК та вносити до системи всі необхідні дані про пацієнта.

За допомогою ICРC-2 можна кодувати симптоми, синдроми, скарги, коли неможливо встановити точний діагноз, що забезпечує зручність системи. Система робить точнішим та простішим ведення обробки медичних записів в електронному вигляді, всієї медичної статистики. Необхідність зберегти діагнози особи у таємниці $\epsilon$ причиною необхідності шифрувати хвороби.

Полегшення обміну інфрормацією з іншими медичними установами, широкі можливості аналізу даних $€$ ключовими перевагами введення за допомогою шаблонів інформації в карту пацієнта та збереження іï̈ в структурованому вигляді. Зручна система пошуку даних дозволяє легко у великих об'ємах медичної документації знайти необхідну інформацію. Використовуючи підпрограми статистичної обробки даних, надається можливість легко та швидко підготувати необхідні звіти відповідно до вимог контролюючих органів, Міністерства охорони здоров'я. 


\begin{tabular}{|c|c|c|}
\hline \multicolumn{3}{|c|}{ ПЕРЕВАГИ ВИКОРИСТАННЯ ЕЛЕКТРОННОГО РЕЦЕПТУ } \\
\hline & & \\
\hline $\begin{array}{c}\text { для сфери охорони здоров'я } \\
\text { (розпорядника бюджетних } \\
\text { коштів) } \\
\text { надає інструменти для } \\
\text { ефективного управління } \\
\text { державними коштами; } \\
\text { дозволяє вести облік аптек, } \\
\text { що працюють за програмами, } \\
\text { та укладених угод, моніторинг } \\
\text { виписаних рецептів та } \\
\text { фінансовий моніторинг } \\
\text { освоєння бюджетних коштів, } \\
\text { мінімізує випадки відпуску } \\
\text { ліків за пільговими рецептами } \\
\text { з порушенням вимог } \\
\text { програми }\end{array}$ & $\begin{array}{l}\text { для медичних } \\
\text { закладів } \\
\text { зменшує кількість } \\
\text { помилок лікарів при } \\
\text { виписуванні рецептів, } \\
\text { дозволяє виявляти } \\
\text { лікарів, що } \\
\text { виписують рецепти з } \\
\text { порушенням вимог } \\
\text { програми, аналізувати } \\
\text { наявність ліків в } \\
\text { аптеках, } \\
\text { автоматизує } \\
\text { звітність } 3 \\
\text { розпорядником } \\
\text { коштів }\end{array}$ & $\begin{array}{l}\text { для аптечних закладів } \\
\text { унеможливлює відпуск } \\
\text { препаратів за неправильно } \\
\text { виписаним рецептом, } \\
\text { забезпечує реєстрацію } \\
\text { відпуску препаратів за } \\
\text { рецептом, взаєморозрахунки з } \\
\text { розпорядниками коштів за } \\
\text { кожним рецептом, } \\
\text { скорочує час на } \\
\text { обслуговування пацієнта, } \\
\text { дозволяє вести статистику } \\
\text { щодо кількості відпущених } \\
\text { ліків за державною програмою } \\
\text { в реальному часі }\end{array}$ \\
\hline
\end{tabular}

\section{Рис. 3. Переваги використання електронного рецепту в сфері охорони здоров'я}

Захист персональних даних пацієнтів - головна проблема впровадження ЕМК. Електронні записи про здоров'я у розвинених країнах формують не тільки медичну картку. Їх можна переглянути в персональному кабінеті користувача послуг [12].

У 2020 році продовжується запровадження системи "eHealth". Серед закладів та провайдерів первинної медичної допомоги, які уклали договір з НСЗУ, зріс рівень комп'ютеризації до $92 \%$. 3 вересня 2019 року більше ніж 50 закладів первинної ланки приєдналися до тестування електронних медичних записів за класифрікацією ICPC-2. Одним з пріоритетів Уряду є запровадження ведення медичної документації в електронному вигляді.

Електронний рецепт може використовуватись як електронний реєстр пільгових ліків на базі унікального коду лікарських засобів. За такими окремими протоколами (API) медичні заклади можуть здійснювати автоматизований обмін даними, використовувати коди препаратів для власного товарно-матеріального обліку та інших потреб. Система надає доступ до даних призначень лікарям, фрармацевтам, розпорядникам коштів і при цьому повинна бути захищена від проникнення сторонніх осіб.

При впровадженні електронного рецепту в практику медичних закладів лікарі за допомогою медичної інформаційної системи медичного закладу оформлюють рецепти в електронній системі охорони здоров'я.

Позитивним моментом також $є$ можливість відійти від використання стандартних паперових бланків рецептів і перейти на електронні послуги. Переваги використання електронного рецепту представлено на рисунку 3.

Розвиток інфрраструктури електронної ідентифікації сприятиме розвитку електронних форм взаємодії держави та громадян, дасть змогу забезпечити безпечний та зручний доступ суб'єктів господарювання та громадян до інтерактивних інструментів, різноманітних електронних послуг, визначених даних з інфоормаційних систем органів влади без використання в різних інформаційних системах декількох облікових записів.

У сегменті розвитку е-медицини необхідними напрямами розвитку залишаються: ведення медичної документації в електронному вигляді; впровадження інформаційних автоматизованих галузевих систем; впровадження телемедицини; удосконалення розвитку системи моніторингу стану здоров'я населення; впровадження та створення новітніх комп'ютерних технологій діагностики, профрілактики захворювань, забезпечення лікувальних процесів; створення електронних загальнодоступних медичних ресурсів;побудова методами е-медицини власної парадигми здоров'я та розробка методів самодіагностики [7].

\section{ВИСНОВКИ}

У статті визначено механізми впровадження електронного рецепту, електронної медичної картки в практику медичних закладів охорони здоров'я, реалізація яких зменшить кількість помилок при обліку рецептів і відпуску препаратів та скоротить час на обслуговування пацієнтів. Доведено, що підтримка та розвиток безпечних, прозорих та доступних, електронних послуг дасть змогу підвищити конкурентоспроможність та мобільність публічних послуг, покращити якість їх надання юридичним та фрізичним особам, зменшити корупційні ризики.

У реалізації другого етапу ресоорми сфери охорони здоров'я України $є$ доречним завершити диджиталізацію галузі, забезпечити повний електронний документообіг у системі охорони здоров'я, забезпечити розбудову системи оцінювання медичних технологій, підвищити якість медичних послуг, які надаються населенню; забезпечити функціонування доступної та спроможної мережі спеціалізованих закладів охорони здоров'я для надання якісних медичних послуг; розширення доступу пацієнтів, що користуються програмою "Доступні ліки", до нових лікарських засобів та забезпечення доступу пацієнтів до якісних та безпечних лікарських засобів.

\section{Література:}

1. Програма діяльності Уряду. URL: https:// www.kmu.gov.ua/diyalnist/programa-diyalnosti-uryadu (дата звернення 05.11.2021). 
2. Баценко Д., Брагінський П., Бучма М. Як організувати систему надання первинної медичної допомоги на місцевому рівні. Операційне керівництво. Київ: ТОВ "Агентство "Україна", 2018. 368 с.

3. Орлова Н.С. Механізми державного управління у реформуванні системи охорони здоров'я. Публічне адміністрування та національна безпека. 2019. №6. URL: https://doi.org/10.25313/2617-572X-2019-6-5377 (дата звернення: 05.11.2021).

4. Радиш Я.Ф. Державна політика у сфері охорони здоров'я: колективна монографія. Київ: НАДУ, 2013. 396 с.

5. Устінов О.В. Стратегія державної політики у сорері охорони здоров'я. Український медичний часопис. URL: https://www.umj.com.ua/article/35657/strategiyaderzhavnoi-politiki-u-sferi-oxoroni-zdorov-ya (дата звернення 05.11.2021).

6. Деякі питання електронної системи охорони здоров'я: постанова Кабінету Міністрів України від 25 квітня 2018 p. № 411. URL: https: / / zakon.rada.gov.ua/laws / show /411-2018-\%D0\%BF (дата звернення 05.11.2021).

7. Національна стратегія реформування системи охорони здоров'я в Україні на період 2015-2020 років. URL: http://moz.gov.ua/uploads/0/691-strategiya.pdf (дата звернення 05.11.2021).

8. Реформа системи охорони здоров'я. URL: https:/ /www.kmu.gov.ua/ua/diyalnist/reformi/rozvitoklyudskogo-kapitalu / reforma-sistemi-ohoroni-zdorovya (дата звернення 05.11.2021).

9. Статистична інформація. Державна служба статистики України. URL: http://www.ukrstat.gov.ua/ (дата звернення 05.11.2021).

10. Как будет работать e-Health: без медкарты и с электронными рецептами. URL: https://24tv.ua/ health/ru/kak_rabotaet_e_health_kabinet_pacienta_i_jelektronnye_bolnichnye_n 1093222(дата звернення 05.11.2021).

11. Супрун У. Плани змін в охороні здоров'я у 2019 році. Дайджест змін в охороні здоров'я. 2018. № 11. URL: https://moz.gov.ua/uploads/1/7988-moz_digest_11_2018.pdf (дата звернення 05.11.2021).

12. Про схвалення Концепції рефрорми фрінансування системи охорони здоров'я: розпорядження Кабінету Міністрів України від 30 листопада 2016 р. № 1013-р. URL: https://zakon.rada.gov.ua/laws/show/10132016-\%D1\%80(дата звернення 05.11.2021).

References:

1. The official site of Government Portal (2020), "Government activity program", available at: https:// www.kmu.gov.ua/diyalnist/programa-diyalnosti-uryadu (Accessed 5 Nov 2021).

2. Batsenko, D., Brahins'kyj, P. and Buchma, M. (2018), Yak orhanizuvaty systemu nadannia pervynnoi medychnoi dopomohy na mistsevomu rivni. Operatsijne kerivnytstvo [How to organize the system of primary health care at the local level. Operational management], TOV "Ahentstvo "Ukraina", Kyiv, Ukraine.

3. Orlova, N. S. (2019), "Mechanisms of public administration in reforming the health care system", Publichne administruvannia ta natsional'na bezpeka, [Online], vol. 6, available at: https://doi.org/10.25313/ 2617-572X-2019-6-5377 (Accessed 5 Nov 2021).
4. Radysh, Ya. F. (2013), Derzhavna polityka u sferi okhorony zdorov'ia: kolektyvna monohrafiia [Government policy in the field of health care: a collective monograph], NADU, Kyiv, Ukraine.

5. Ustinov, O.V. (2012), "Public health policy strategy", Ukrains'kyj medychnyj chasopys, [Online], available at: https://www.umj.com.ua/article/35657/strategiyaderzhavnoi-politiki-u-sferi-oxoroni-zdorov-ya (Accessed 5 Nov 2021).

6. Cabinet of Ministers of Ukraine (2018), Resolution "Some issues of the electronic health care system", available at: https://zakon.rada.gov.ua/laws/show/ 411-2018-\%D0\%BF (Accessed 5 Nov 2021).

7. The official site of Ministry of Health of Ukraine (2020), "National strategy for health care reform in Ukraine for the period 2015-2020", available at: http://moz.gov.ua/ uploads /0/691-strategiya.pdf (Accessed 5 Nov 2021).

8. The official site of Government Portal (2020), "Health care reform", available at: https://www.kmu.gov.ua/ua / diyalnist/reformi/rozvitok-lyudskogo-kapitalu/reformasistemi-ohoroni-zdorovya (Accessed 5 Nov 2021).

9. The official site of Government Statistics Service (2021), "Statistical information", available at: http:// www.ukrstat.gov.ua/(Accessed 5 Nov 2021).

10. The official site of "Channel 24 health" (2019), "How e-Health will work: without a medical card and with electronic prescriptions", available at: https://24tv.ua/ health/ru/kak_rabotaet_e_health_kabinet_pacienta_i_jelektronnye_bolnichnye_- 1093222 (Accessed 5 Nov 2021).

11. Suprun, U. (2018), "Healthcare change plans for 2019", Dajdzhest zmin v okhoroni zdorov'ia, [Online], vol.11., available at: https://moz.gov.ua/uploads/1/ 7988-moz_digest_11_2018.pdf (Accessed 5 Nov 2021).

12. Cabinet of Ministers of Ukraine (2016), Resolution "On approval of the Concept of health care financing reform", available at: https: / / zakon.rada.gov.ua/laws / show /1013-2016-\%D1\%80 (Accessed 5 Nov 2021). Cтаття надійшла до редакиї 09.11.2021 p.

\section{www. economy.nayka.com.ua} Електронне фахове видання

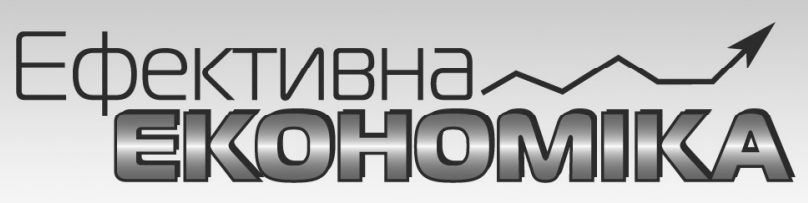

\section{Виходить 12 разів на рік}

Журнал включено до переліку наукових фахових видань України з ЕКОНОМІЧнИХ НАУК (Категорія «Б»)

Спеціальності - 051, 071, 072, 073, 075, 076, 292

e-mail: economy_2008@ukr.net тел.: (044) 223-26-28 (044) $458-10-73$ 